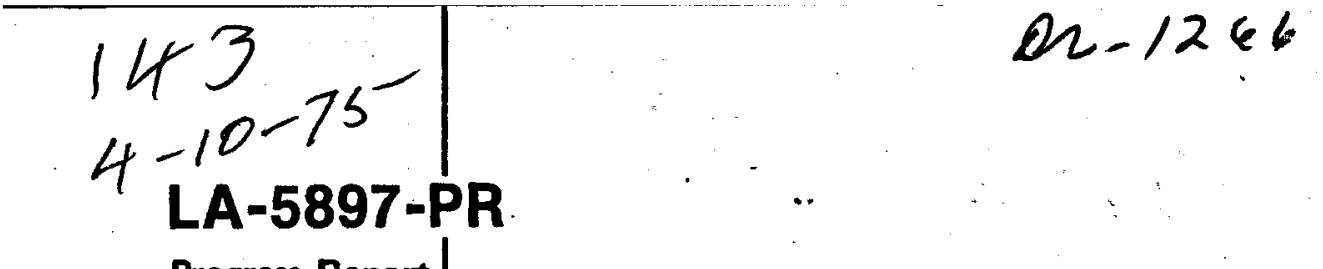

UC-13

Reporting Date: February 1975 Issued: March 1975

\title{
Testing, Drilling, and Logging of Geothermal Test Hole GT-2, Phase II
}

by

Roland A. Pettitt 


\section{DISCLAIMER}

This report was prepared as an account of work sponsored by an agency of the United States Government. Neither the United States Government nor any agency Thereof, nor any of their employees, makes any warranty, express or implied, or assumes any legal liability or responsibility for the accuracy, completeness, or usefulness of any information, apparatus, product, or process disclosed, or represents that its use would not infringe privately owned rights. Reference herein to any specific commercial product, process, or service by trade name, trademark, manufacturer, or otherwise does not necessarily constitute or imply its endorsement, recommendation, or favoring by the United States Government or any agency thereof. The views and opinions of authors expressed herein do not necessarily state or reflect those of the United States Government or any agency thereof. 


\section{DISCLAIMER}

Portions of this document may be illegible in electronic image products. Images are produced from the best available original document. 
The previous report in this series, unclassified, is LA-5819-PR. In the interest of prompt distribution, this report was not edited by the Technical Information staff.

Printed in the United States of America. Available from National Techrical Information Service

US Department of Commerce

5285 Port Royal Rood

Springtield, VA 22151

Price: Printed Copy $\$ 4.00$ Microfiche $\$ 2.25$

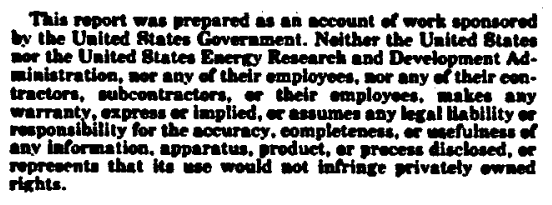


NOTICE

This report was prepared as an account of work sponsored by the United States Government. Neither the United States nor the United States Energy Research and Development Administration, nor any of their employees, nor any of their contractors, subcontractors, or their employees, makes any warranty, express or implled, or assumes any legal liability or responsibility for the accuracy, completeness or usefulness of any information, apparatus, product or process disclosed, or represents that its use would not process disclosed, or represents that its use would not infringe privately owned rights.

TESTING, DRILLING, AND LOGGING OF GEOTHERMAL TEST HOLE GT-2, PHASE II

by

Roland A. Pettitt

ABSTRACT

Geothermal Test Hole No. 2 (GT-2) is a deep exploratory hole drilled into the Precambrian-age granitic rocks underlying the Jemez Mountains of north-central New Mexico. The purpose of the hole is to confirm the sultability of the Fenton Hill site for development of the world's first dry. hot rock geothermal energy extraction experiment. Due to recent volcanic activity in the area, the near-surface rocks still retain a great amount of heat.

The drilling of GT-2 to a depth of $1937 \mathrm{~m}$ (6356 ft) was completed in June 1974. Following the drilling, a series of hydrology experiments was performed to determine the permeability of the granitic rock at depth. Hydraulic fracturing experiments, using methods and equipment developed by the oil-well service industry, were conducted at specific zones in the granitic section of the hole. An additional $105 \mathrm{~m}$ ( $345 \mathrm{ft}$ ) of drilling were completed during this testing phase to allow experiments to be conducted in a "fresh" hole. Various diagnost1c-1ogging operations were performed during testing and drilling. This report describes the second phase of the development of GT-2.

\section{INTRODUCTION}

The primary objective of the Los Alamos Dry Geothermal Source Demonstration Project is to Invest1gate and develop methods of extracting energy economically from hot rock in the earth's crust. This will Involve large-scale field studies and demonstrations of drilling into hot rock, fracturing it by hydraulic pressure or by other methods to produce connected circulation paths through the rock, and then circulating water or other flutds through these channels to extract heat from the rock and transport it to the earth's surface. It wili Include research and development In those areas of geochemistry, geophysics, heat flow, fluid flow, rock mechanics, selsmology, environmentel effects, and related subjects, which are required to make such an energyextraction system successful, economical, and environmentally acceptable. 1,2

Throughout the Iffe of the project, a major objective will also be to make this new technology ava1lable to industry as soon as Its usefulness has been demonstrated.

The geothermal source demonstration area 18 located on the Jemez Plateau, which 18 part of the western arm of the Rocky Mountains extending Into northern New Mexico (F1g. 1). As a result of relatively recent vulcanism, a large amount of heat 18 still retained in rocks underlying the entire area whin a few kilometers of the surface.

The geology of this region was first described by Renich, ${ }^{3}$ and has since been described by Woods and Northrop, ${ }^{4}$ Silth et aln ${ }^{5}$ Ross et al, ${ }^{6}$ and Balley et al. 7 A regional geologic map was published by Smith et al. 8 Fitzsimons ${ }^{9}$ described some of the Precambrian rocks in the area and West ${ }^{10}$ has discussed the geophysics of the Jemez Mountains.

The Los Alamos Scientific Laboratory (LASL) 18 located on the eastern flank of the Jemez Mountains, about $50 \mathrm{~km}$ ( $30 \mathrm{mtles}$ ) by road from the demonstration area. 


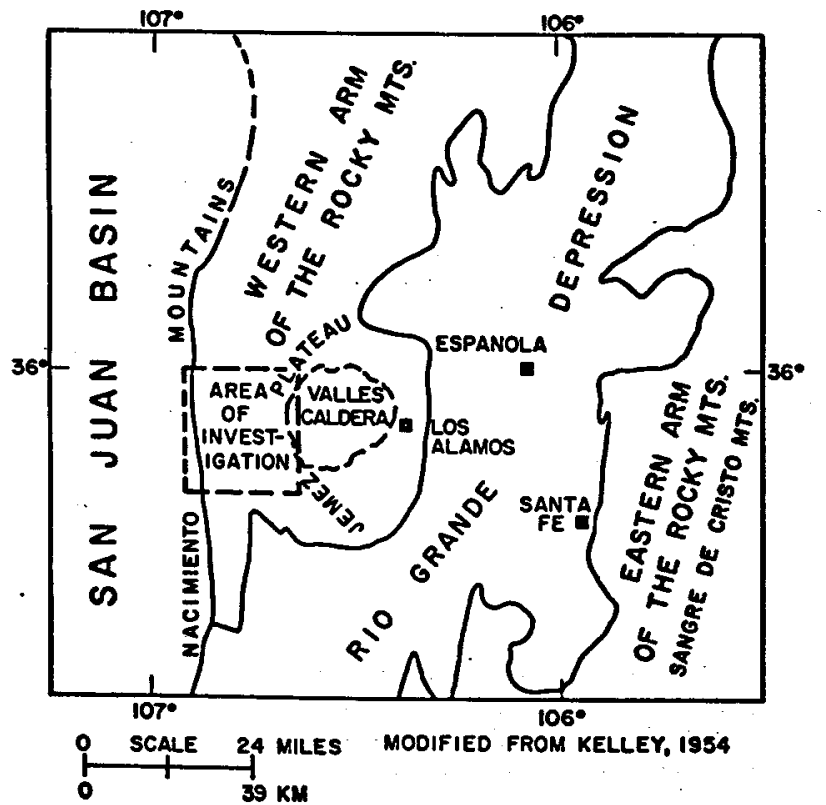

Fig. 1. Major structural features and area of investigation in north-central New Mexico.

On the basis of previous studles, surveys, and field experiments, ${ }^{11-13}$ a specific site on the Jemez Plateau west of Los Alamos was selected as an appropriate location for development of the first dry hot rock energy experiment. It has been officially identified as "The Fenton Hill site," or TA-57 (LASL Technical Area 57).

This report presents a chronological history of the work done and some of the problems encountered in testing, drilling and logging during the second phase of work in GT-2. More detalled descriptions of Individual parts of the work and the conclusions that were drawn from interpretation of the test data will be presented in forthcoming reports by others.

\section{SUMMARY OF PHASE I WORK}

Drilling began in GT-2 on February 17, 1974. Serious problems encountered in drilling the Permianage red beds and the Pennsylvanlan-age shales and IImestones required a string of 34-cm-diam (13-3/8in.) casing to be set to a depth of $488 \mathrm{~m}$ (1600 ft). The Precambrian granitic surface was reached at a depth of $733 \mathrm{~m}$ (2404 ft) on March 30, but caving of the overlying sedimentary rock formations continued to present difficulties. A second string of 27.3cm-diam (10-3/4-1n.) casing was set from the surface to a depth of $773 \mathrm{~m}(2535 \mathrm{ft})$. Drilling continued
In the granitic basement rocks to a depth of $1937 \mathrm{~m}$ (6356 ft). A detalled account of the planning, drilling and logging of the first phase of GT-2 has been presented in a previous report. ${ }^{14}$

The geologic section of the first phase of the project has been reported by Purtymun et al. 15

The elevation of the top of the Kelly bushing was $2652 \mathrm{~m}$ (8701.5 ft) above mean sea level, and all depths in Phase I and II were measured from this point.

\section{PLANNING OF PHASE II WORR}

A detalled plan of the proposed Phase II postdrilling measurements for GT-2 was prepared in December 1973. The revised version of this plan, dated March 20, 1974, is Included as Appendix A of this report.

The plan outlined the sequence of operations to be followed immediately after the drilling (Phase I) had been completed. A number of post-drilling measurements and experiments were also listed. The primary objective of the testing was to obtain additional hydrologic, geologic and in situ earth-stress and fracture-mechanics information to make a deciston whether to proceed with the development of the energy demonstration project at the Fenton Hill site.

Because of changed conditions and unforeseen events, some parts of the plan were not accomplished In the way that had been outlined. These changed aspects of the work will be discussed in the concluding section of this report.

\section{GEOPHYSICAL INVESTIGATIONS}

A. Selsmic Net Installation

In the planning for the experiments in GT-2, the Implantation of a series of selsmic 11stening posts was considered to be a vital part of the project. Use of the stations was to be two-fold: (1) to detect the sonic events associated with the initiation and propagation of the downhole fracture and thus to plot 1ts location; and (2) to monftor the hydraulic fracture experiments to obtain advance warning if stresses were building up which might cause earth tremors in the area.

During the first-phase drilling program in the spring of 1974, the construction of the selsmic net was begun. Two LASL groups each Installed their own ring of stations around the drill site. These 


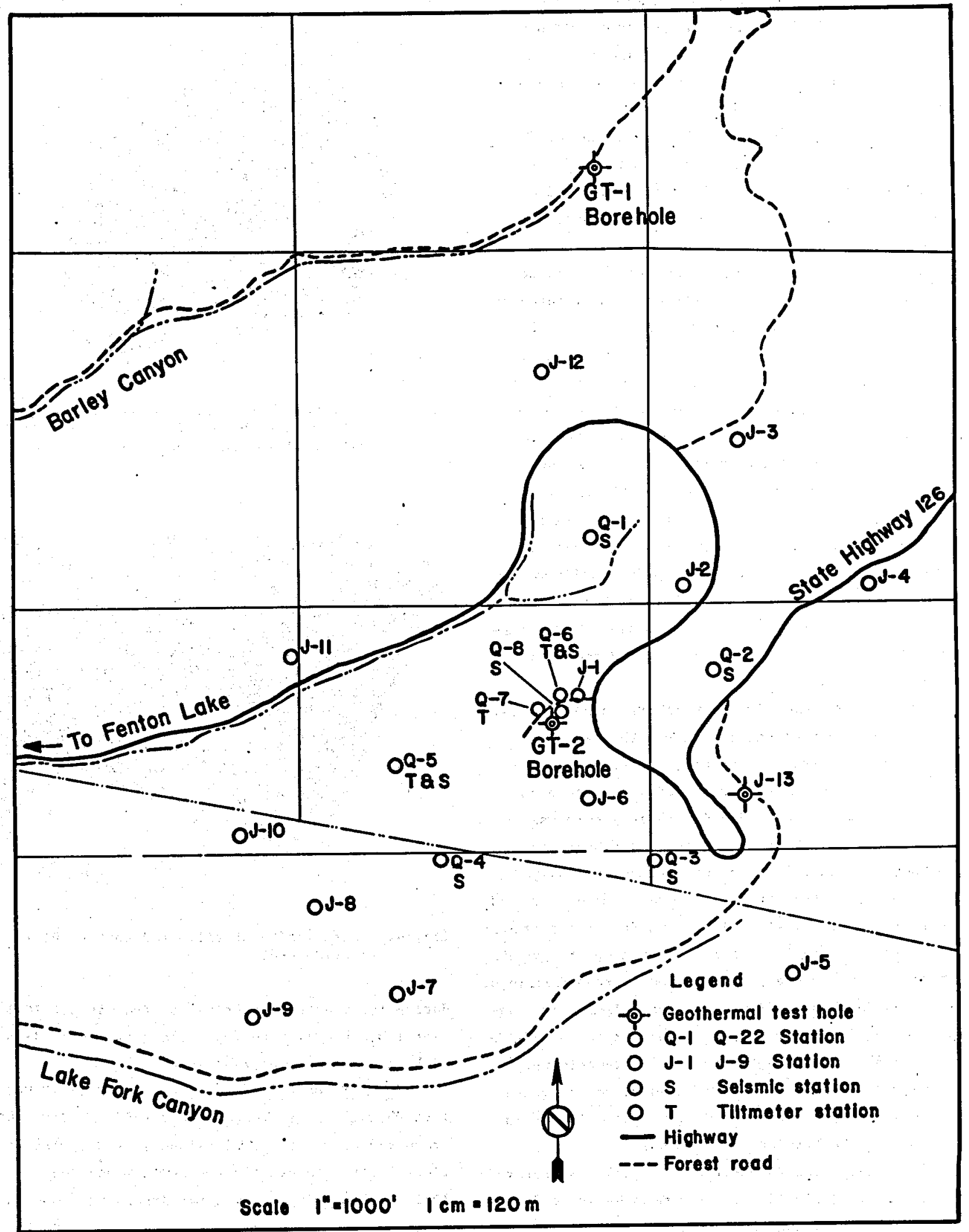

Fig. 2. Locations of selsmic and tiltmeter stations at the Fenton Hill Site. 
separate installations served to complement each other as one set of stations was located within a 762-m (2500-ft) radius of GT-2, and the other set was farther away and was tied in with the regional seismic net (Fig. 2).

1. Q-22 Insta1lations. The LASL Geothermal Group is designated as Q-22. The stations that were installed and operated by this group consisted of $\mathbf{s i x}$ seismic stations and four tiltmeter stations, with two of the installations Intended to house both seismic and tiltmeter equipment. Four of the seismic stations and one combination station were located on an arc with a radius of approximately $762 \mathrm{~m}(2500 \mathrm{ft})$ from the drill hole. One other combination station and a tiltmeter installation were placed at a radius of $152 \mathrm{~m}(500 \mathrm{ft})$, and one tiltmeter at a distance of $30 \mathrm{~m}(100 \mathrm{ft})$. Relative elevations of the stations ranged from $50 . \mathrm{m}$ (164 ft) below the groundlevel elevation of GT-2 to $10 \mathrm{~m}$ (33 ft) above.

The general procedure for the construction of the Q-22 stations was to excavate a 2- to 3-m-dtam hole (6- to 10-ft), 2- to 3-m deep Into solid volcanic tuff rock, pour a $15-\mathrm{cm}-t h i c k$ (6-1n.) concrete slab at the bottom, install a 1.2-m-diam (4-ft) corrugated metal pipe with hinged 11d, and backfill around the pipe.

Three Teledyne S-13 seismometers were installed at each seismic station, together with low-noise amplifiers, lightning arrestors, batteries, associated terminal boxes and wiring (Fig. 3). At each tiltmeter station, a 10-cm-diam (4-in.) hole was drilled through the concrete slab and a North American Rockwell biaxial t1ltmeter placed vertically in the hole. Selected, graded sand was tamped in around the tiltmeter (Fig. 4). All wiring from the stations to the instrumentation trailer was run on the ground surface, except where it was burfed at road crossings. Considerable difficulty was experienced in keeping the stations operational during the summer lightning-storm season. The tiltmeter instruments were severely damaged by lightning in July, and only the close-in tiltmeter station, Q-8, was used to obtain data during the fracture experiments.

2. GT-1. The 785-m-deep (2575-ft) exploratory drill hole in Barley Canyon, known as Geothermal Test Hole No. 1 (GT-1) and located $2.6 \mathrm{~km}$ ( $1.6 \mathrm{mile}$ ) north of GT-2, was instrumented with a downhole geophone set approximately $15 \mathrm{~m}(50 \mathrm{ft}$ ) off bottom (Fig. 5). This hole served as an additional listening post 4

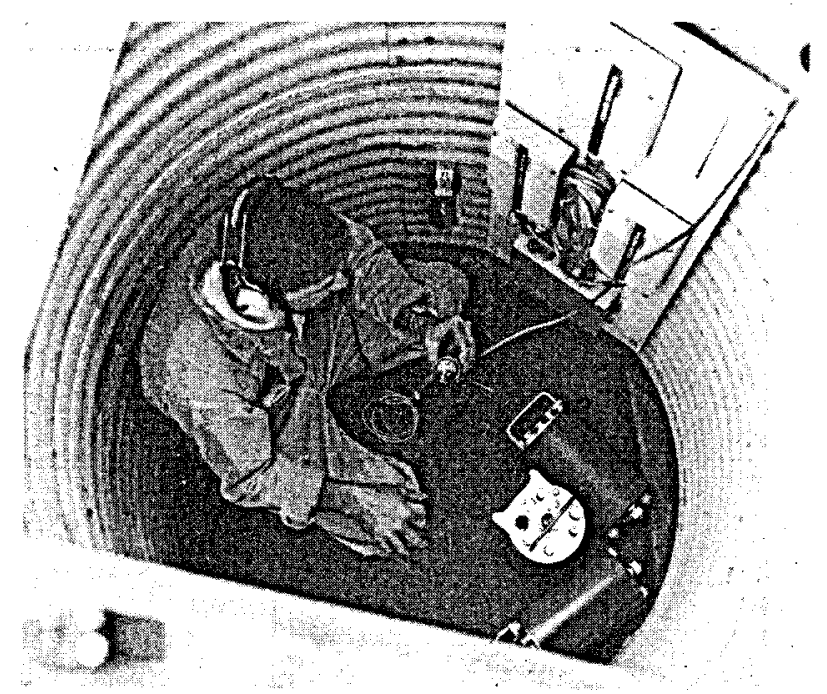

F18. 3. Interior of typical Q-22 selsmic station, showing the three selsmometers, terminal boxes, wiring and lightning arrestors.

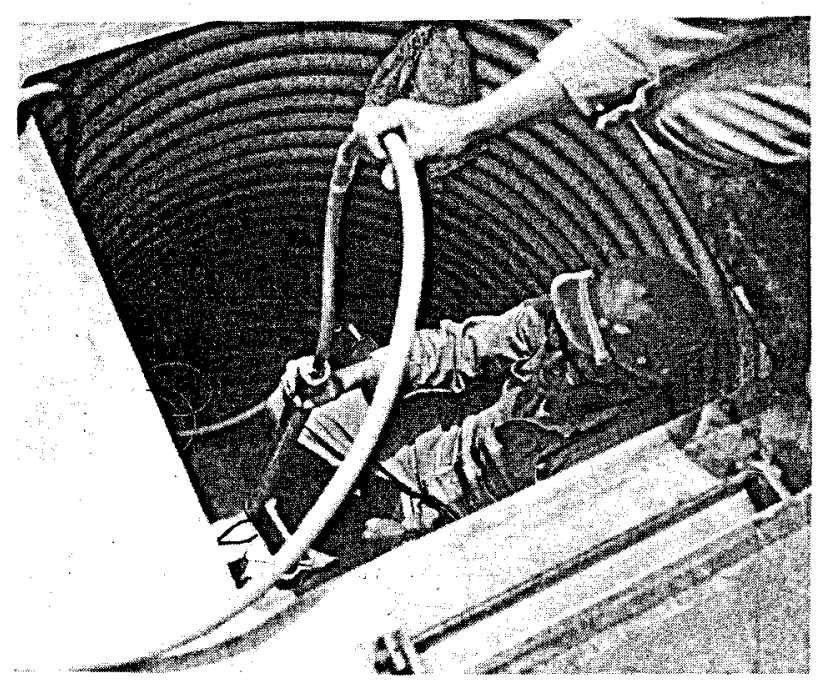

Fig. 4. Installation of tiltmeter instrument in Station Q-8.

during the fracture experiments, and was particularly useful because it afforded a means to couple directly with the Precambrian granitic rock.

3. J-9 Installations. The LASL Underground Test Phenomenology Group is designated as J-9. This group has operated a regional seismic net with stations located throughout the Jemez Mountains since 1972. An outlying selsmic net around GT-2 was installed, with the farthest station being $1888 \mathrm{~m}$ (6194 ft) away and the closest a distance of $164 \mathrm{~m}$ (537 ft). 


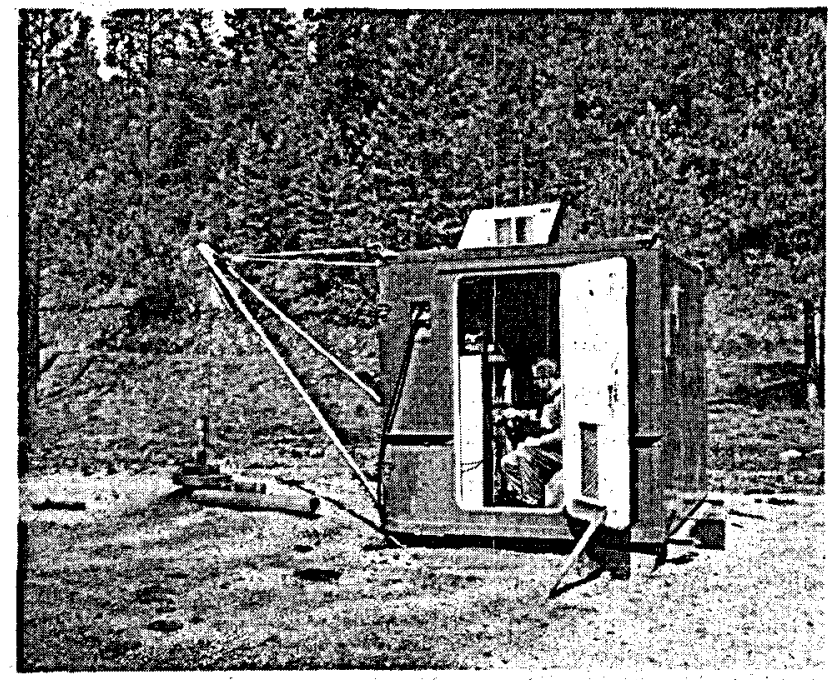

F1g. 5. Instrumentation van for downhole geophone at Geothermal Test Hole No. 1 (GT-1).

Holes with a depth of approximately 1 m ( $3 \mathrm{ft}$ ) were excavated, a concrete base was poured in the bottom, and a 40-cm-diam (16-1n.) metal can placed on the pad. A single geophone was placed at each station: Teledyne Geotech Model $\mathrm{S}-13$ at Stations J-5, $\mathrm{J}-7, \mathrm{~J}-10$, and $\mathrm{J}-12$; Mark Products, Inc. Model L4-3D at Stations $\mathrm{J}-2$ and $\mathrm{J}-6 ;$ and Geospace Corp. Model HS-10 at the remalnder. Two $12-V$ wet-cell batterles were used at each station in confunction with a power amplifier untt, placed on top of the can and wrapped In plastic.

Station J-13 was a 180-m-deep (590-ft) exploratory drill hole in Lake Fork Canyon, about $915 \mathrm{~m}$ (3000 ft) southeast of GT-2, A Wilcoxon Research Company Model H-86 hydrophone was placed at a depth of $170 \mathrm{~m}$ (557 ft), a distance of $17 \mathrm{~m}$ (56 ft) below the water surface in the hole.

4. GT-2 Geophone Package. A geophone package to be used to detect sonic events in GT-2 during the fracture experiments was designed and fabricated by LASL Group Q-22, using standard stock components. The instrument consisted of a triaxial-geophone array, 8-Hz frequency, tested to withstand $200^{\circ} \mathrm{C}$; and a bonded strain-gauge-type pressure gauge, $51.7 \mathrm{MPa}$ (7500 psia), temperature compensated for 50 to $200^{\circ} \mathrm{C}$. The package had a maximum diameter of $9.2 \mathrm{~cm}$ (3.6 In.) to fit Inside the drill pipe. The package was also fitted with an orlenting shoe st the upper end, so that the azimuthal alignment of the geophone could be determined.

\section{B. Resistivity Net}

1. LASL Q-22 Operations. Two lines for surface resistivity determinations were centered on GT-2 at about a 60-degree angle to each other. These were installed to determine variations in the deepresistivity values during the hydraulic fracturing experiments.

Each line extended for a distance of $3 \mathrm{~km}(1.9$. mile) on both sides of the drill hole. One line was oriented In an approximate north-northesst direction and the other in an east-northeast direction. It was planned to set a dipole transmitter at various locations along each ine and to make potential difference measurements at $250-\mathrm{m}(820-f t)$ Intervals along the opposite line.

2. Untversity of New Kextco Operations. The Untversity of New Mexico (UNM) Geology Department also Installed two transmitting lines in the Fenton H111 area, One IIne extended down Lake Fork Canyon (just south of Fenton Hili) in an east-west direction and the other extended in a north-south direction from Lake Fork Canyon to Fenton Lake. Transmisstons were made from along these lines to varlous receiving points along existing forest roads on the mesa tops and in the valleys. Transmissions were made at 10 to 15 amps, at very low frequencies.

\section{c. Sonic Velocity Calibrations}

B1rdwell Logging Company conducted sonic-velocIty calibration measurements from the Q-22 and $\mathrm{J}-9$ selsmic stations around the drill hole. The Birdwell "Vibroseis" truck was positioned near each seismic station, and sonic velocities were recorded from the ground surface to the downhole geophone at depths of 1372,1593 , and $1783 \mathrm{~m}(4500,5225$, and $5850 \mathrm{ft})$ in GT-2 (Fig. 6).

D. Selsmic Survey of Area

During July, a seismic survey of the general area around GT-2 was conducted by the J. W. Cooksley Company of Tucson, Arizona. The purpose of the survey was to locate faults in the near-surface structure and to obtain generallzed geological information on the deep structure as an ald In selecting sites for future holes in the Immediate vicinity. Both reflection and refraction sefsmic methods were employed. Small dlameter holes were drilled 5- to 20-m deep (15- to 65-ft) into the volcanic tuff, and were loaded with 113-g (0.25-1b) sticks of dynamite. One Iine of holes ran for sbout $4 \mathrm{~km}(2.5 \mathrm{miles})$ down 


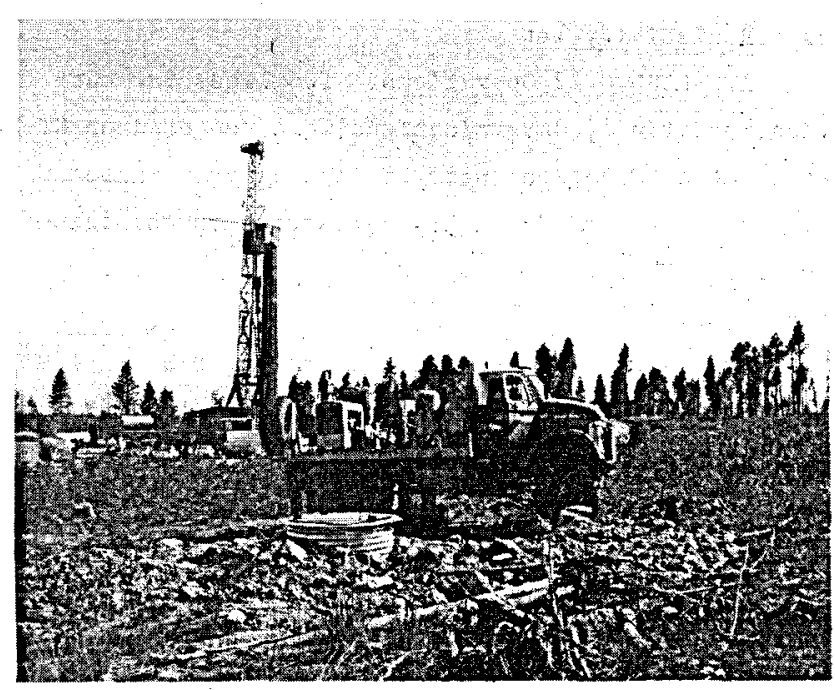

F1g. 6. "V1broseis" truck unit used to conduct sonic velocity callbration measurements from seismic stations to drill hole. Thumping device to supply energy for the sonic signal is positioned near back wheels. Station $Q-6$ is seen in front of truck.

Lake Fork Canyon. The shots fired in these holes were recorded on the mesa top to the north. Another series of shots was made at 200-m (656-ft) spacings on a line angling northwest across the center of the drill hole.

All selsmic signals were recorded on magnetic tape for future filtering and computer enhancement work.

\section{HYDROLOGY EXPERTMENTS}

A. Purpose

As soon as the drilling and logging operations had been completed in GT-2, a set of measurements employing drill-stem-testing techniques was planned to determine the prefracturing permeability. of the Precambrian rock below the casing. The purpose of these tests was to determine the permeability of the exposed basement rock at various intervals in the hole. Because the successful operation of a twohole dry hot rock geothermal energy system is largely dependent on the impermeable quality (watertightness) of the basement rock, it was important to determine the least permeable sections of the hole for conducting the fracture experiments.

B. Depths Tested

Hydrology testing began on July 17 and continued unt11 August 4, when it was essentially completed.
Approximately 16 tests were conducted in the 792- to 884-m (2600- to 2900-ft) and 1433- to 1890-m (4700to $6200-f t$ ) depths of the hole. Packer spacings ranged from a minimum of $27 \mathrm{~m}(90 \mathrm{ft}$ ) to a maximum of $124 \mathrm{~m}$ (408 ft). On September 8, after the hole had been deepened to $2042.6 \mathrm{~m}(6701.5 \mathrm{ft})$, an additional hydrology test was conducted in the section of the hole below $1981 \mathrm{~m}$ ( $6500 \mathrm{ft}$ ).

\section{c. Test Procedure}

All packers used in the hydrology tests were furnished by the Johnston Division of Schlumberger Limited. The usual procedure was to make up a straddle packer assembly consisting of two packer elements, spaced $3 \mathrm{~m}$ (10 ft) apart, set above a hook-wall anchor at the lower end of the pipe string with another similar two-packer assembly inserted in the pipe string at the selected spacing interval.

Sections of the hole to be tested were selected on the basis of data obtained from the geophysical logs, with the caliper $10 \mathrm{~g}$ being used very effectively to determine depths in the hole that were closest to bit-gauge diameter, where the anchors and packers would have the best chance of seating.

In the two instances in which the bottom section of the hole was tested, a string of drill collars was made up to rest on the bottom of the hole with the packer assembly inserted in the string for positioning at the top of the test interval.

1. Flow Testing. After the packer assembly had been set in a predetermined zone, the drill pipe was partially filled with water to prevent possible steam blow-offs during the flow tests. The main control valve in the multiflow evaluator (MFE) system of the Johnston packers was then opened to allow Inflow of water from the formation. (This control valve is sequentlally opened and closed by up-anddown motion of the drill stem.) Flow tests of 2to 4-h duration were normally conducted. At the end of a completed series of flow tests, a $2500 \mathrm{ml}$ (0.66 gal) sample of formation fluid (or drill-hole fluid) was trapped in the MFE sampler chamber and brought to the surface for analysis.

\section{Shut-In Pressure Testing. When the flow} test was completed at each zone, the MFE valve was closed and an 8- to $12-\mathrm{h}$ pressure test was conducted. During this time, the pore-fluld pressure in the rock isolated by the packer assembly was obtained. Pressures were recorded on a metal chart by a diamond- 
tipped stylus at the end of a bourdon tube within a section of the packer assembly.

After a complete sequence of tests had been completed at a specified depth, the assembly was pulled up the hole and set at the next higher zone to be tested. Normally, two separate flow tests and shut-In pressure tests were made at different depths before the packer assembly was withdrawn from the hole.

3. Infection Testing. Upon completion of the second flow and shut-in pressure test, the MFE valve was opened and the drill pipe filled with water to the surface. The decrease in water level in the pipe was observed for periods up to $4 \mathrm{~h}$ to measure the rate at which the formation accepted water. Then the dr111 pipe was pressurized at 1.4 to $2.8 \mathrm{MPa}$ (200 to $400 \mathrm{psi}$ ) above surface hydrostatic, and the rate of infection into the formation was again observed for a 4-h period.

D. Testing Results

The hydrology tests generally Indicated that the granftic rock was relatively impermeable. Those sections of the hole that gave the appearance of being "tight" on the geophysical logs were zones of low permeability in the microdarcy range. The permeability of the rock, at pressures of 1.4 and 2.8 $\mathrm{MPa}$ (200 and $400 \mathrm{psi}$ ) above surface hydrostatic, were low enough to place the rock in the category of being "dry."

E. Equipment Problems

1. Mechanical. Considerable difficulty was experfenced during the early stages of the hydrology testing due to tool malfunctions, leaky pipe, and fittings plugged by drill cuttings. When these problems were corrected, the testing progressed more smoothly.

A procedure was developed to seat the packer assembiy in the casing at a depth of approximately $610 \mathrm{~m}(2000 \mathrm{ft})$ and to cycle the MFE valve several times to determine if it was working properly. Because it normally took 3 to $5 \mathrm{~h}$ to lower the packer assembly to the zone to be tested, this early determination of correct packer operation saved considerable amounts of trip time.

A useful feature of the Johnston straddle packer assembly was the packer by-pass principle. A tube through the packer assembly provides continuous communfcation of fluid from above the top packer to below the bottom packer during a test. This feature gives an imediate surface indication if the bottom packer falls or otherwise becomes Inoperative during testing. However, this feature also allowed the total hole depth (except for the packed-off interval) to be subjected to the hydrostatic water pressure in the annular space between the drill pipe and the borehole wall. As the grantt1c rock accepted small amounts of water over large sections of 1ts depth, the drop in the annulus water level was measurable.

A further procedure, which was developed to check for proper function of the packer sssembly, made use of this continuous drop in the annulus water level. After the packer was seated, measurements of the annulus level were made with the MFE valve both open and closed. If the water-level drop decreased or remained the same after the valve was closed, it was assumed the assembly was functioning properly. If the rate of drop Increased, as occastonally happened when the valve was supposedly closed, it was taken as an Indication that the assembly was not operating properly, and the packers were pulled for Inspection without going through the hydrology test exerclse.

2. Packers. The diameter of the packer elements used in the first few tests was $21.6 \mathrm{~cm}(8-1 / 2$ in.), but after difficulty in trying to seat this size, a 23.2-cm-diam size (9-1/8-in.) proved to be more satisfactory. The rubber packer elements were frequently torn and ruptured from being seated against and dragged across the 1rregular borehole walls. At least one element in the assembly usually needed replacement at the conclusion of each test, but due to the double packer configuration, very 11ttle leakage past the elements occurred during this stage of the testing (F1g. 7 ).

3. Hook-Wall Anchors. Inttially, 21.6-cm-diam (8-1/2-1n.) hook-wall anchor assemblies were used: These were expandable to a diameter of $27.6 \mathrm{~cm}(10-$ $7 / 8$ in.), but were found to be too small for rellable seating in the hole. Subsequently, a 27.3-cm-diam (10-3/4-1n.) anchor assembly was used, which was expandable to $30.5 \mathrm{~cm}$ (12 $\mathrm{in}$.$) , and these proved to$ be satisfactory.

During the first hydrology tests, the replaceable shoes of the hook-wall anchors were made of plain-carbon steel, and no great difficulty was experienced in seating the anchors. When these shoes 


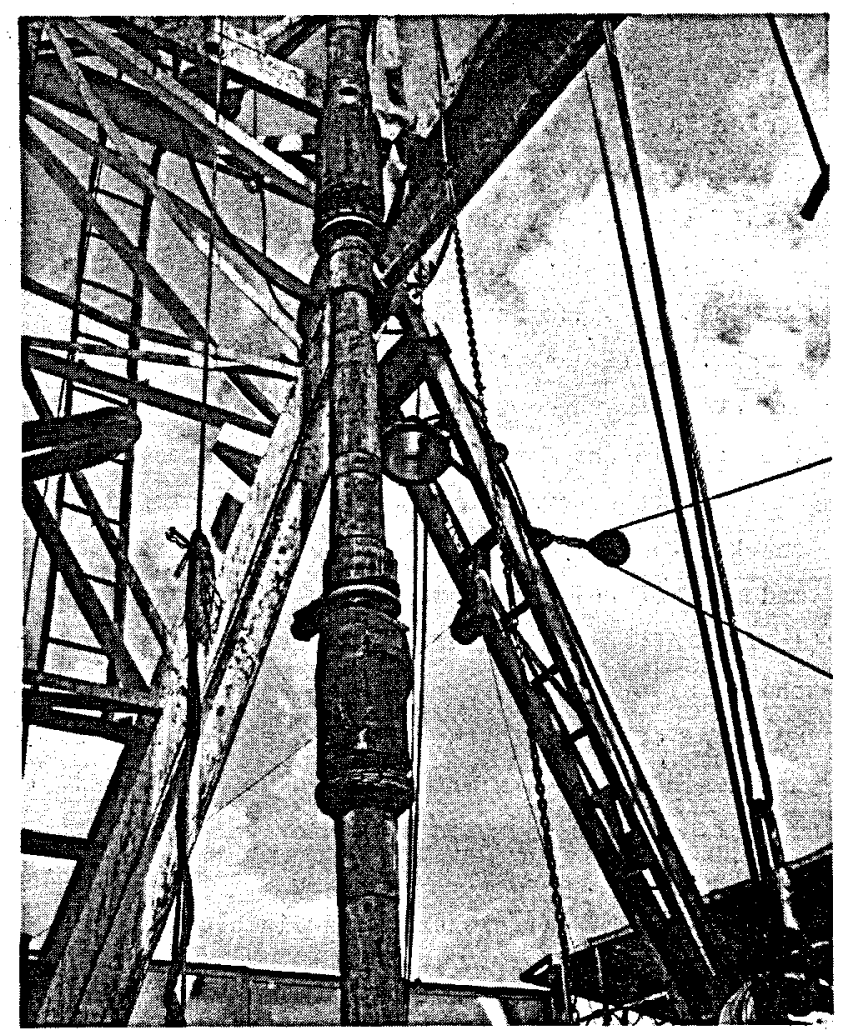

Fig. 7. Double packer element being withdrawn from drill hole. The lower packer element has ruptured, but the upper element is still usable.

became worn, they were replaced with carbide-steel shoes, and seating of the anchors became very difficult. Four or five attempts were usually required before these anchors would seat. It was hypothesized that the carbide-steel anchor shoes were too hard for the rock and that the borehole-wall surfaces in contact with the anchor shoes spalled off under pressure. As soon as the use of softer steel shoes was resumed, this problem disappeared and seating of the anchors was often accomplished on the first try.

VI. FRACTURE EXPERIMENTS--OPEN HOLE

Before continuing with the drilling phase of the planned two-hole energy extraction system at Fenton Hill, It was necessary to obtain specific data on the hydraulic fracturing characteristics of the granitic rock in GT-2. The first fracturing experiments were performed in an open, uncased borehole with the purpose of determining the following information.
(1) Fracture Initiation (breakdown) pressure;

(2) Fracture orientation;

(3) Fracture extension pressure;

(4) Preferred direction of fracture extension;

(5) Fracture fluid leak-off rate;

(6) Pressure-volume relationship of repumped

fracture; and

(7) Determination of least compressive stress.

A. Zones Tested

Fracture experiments began on August 5, and were conducted in six main zones in the open hole. The approximate depths of the zones are defined as
Zone 1

Zone 2

Zone 3

Zone 4

Zone 5

Zone 6

$$
\begin{gathered}
843-873 \mathrm{~m} \\
793-817 \mathrm{~m} \\
1442-1487 \mathrm{~m} \\
1487-1530 \mathrm{~m} \\
1620-1644 \mathrm{~m} \\
1407-1571 \mathrm{~m}
\end{gathered}
$$

(2765-2865 ft)

(2600-2680 ft)

(4730-4880 ft)

(4880-5020 ft)

(5314-5394 ft)

(4617-5153 ft)
These zones were selected from the logs as being the least fractured areas of the hole and being closest to bit-gauge size. The results of the hydrology testing in these zones further Indicated that they were relatively impermeable.

B. Equipment

1. Packer Usage. Johnston packers had been used for all of the hydrology experiments and their use was continued for most of the fracture experiments. Testing with the Johnston packer assemblies continued unt11 August 25, except for a few days when Brown 011 Tool inflatable packers were trled.

The Johnston packers were made up in a straddle packer configuration, with two packers below and two packers above the zone to be tested. Most of the Johnston packer elements were made of 90-durometer hardness rubber, but the last few tests were made with softer elements of 70-durometer hardness.

All zones were pressurized using the Johnston packers at flow rates varying from 4 to $76 \mathrm{l} / \mathrm{min}$ (1 to $20 \mathrm{gpm}$ ). Pressures of 3.4 to $6.8 \mathrm{MPa}$ (500 to 1000 ps1) were usually reached before leakage occurred around the packers. During the first fracture experiments, seismic noises that were created by leakage around the packers were thought to be breakdown or fracture extension signals. Later, these signals were recognized as resulting from leakage, when it was observed that the annulus water level always rose rapidly at the same time. By using 


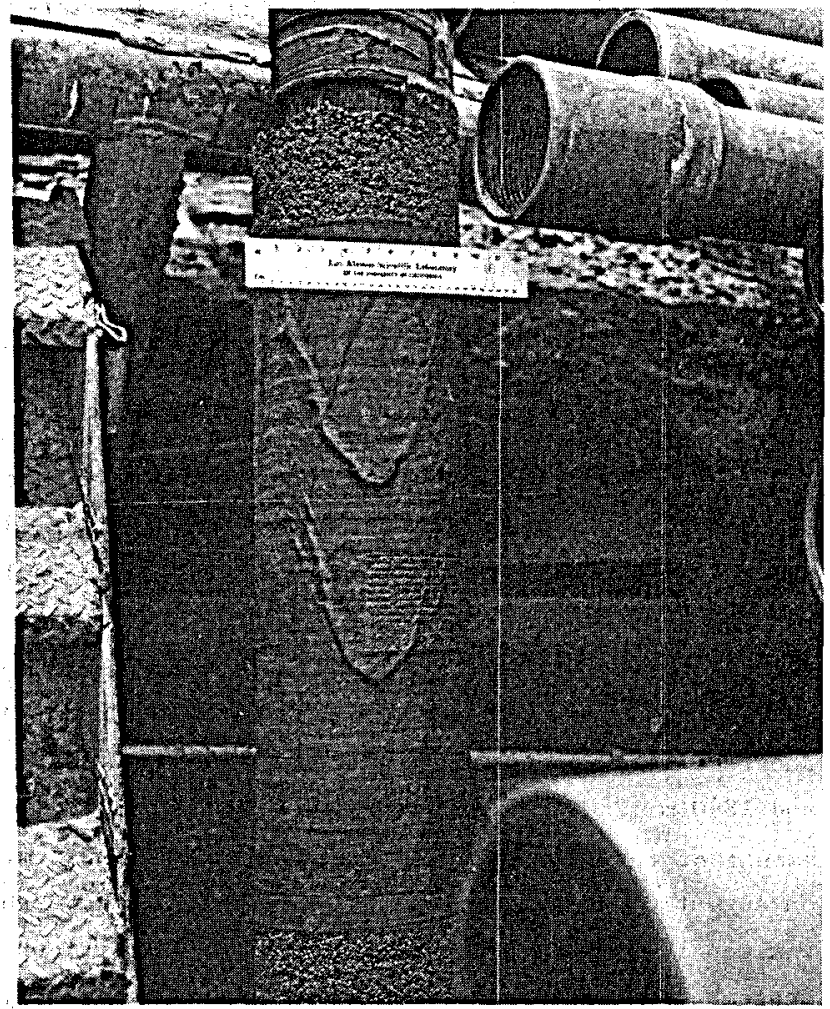

Fig. 8. Impressions of two high-angle fractures remained in the rubber of this Lynes packer element after it was pulled from the borehole.

the softer rubber packer elements, pressures of 11 MPa (1600 psi) were obtained before leakage occurred. Drill-stem welghts on the packers ranged from 36.3 $\mathrm{Mg}$ (80 $000 \mathrm{1bs})$ to $68 \mathrm{Mg}$ (150 $000 \mathrm{lbs})$, but leakage st111 occurred.

A Brown 011 Tool impression packer was used in zone 4 to test for fractures, but no Impressions were obtained. On August 20 and 21, several pressurization tests were made in Zone 5 with the Brown Inflatable packers made up as straddle packers. These tests were also unsuccessful as the packers either burst when Inflated or allowed water to leak past.

From August 26 through 30, and on September 2, Lynes packer elements were used for pressurization tests in Zones 5 and 6. Pressures of $9 \mathrm{MPa}(1300$ ps1) were obtalned before leakage occurred. Maximum Internal-seating pressures for the Lynes packers ranged to $6.1 \mathrm{MPa}(880 \mathrm{psi})$, Fig. 8 .

2. Pressurization Systems. Four systems for pressurizing the hole were avallable during the

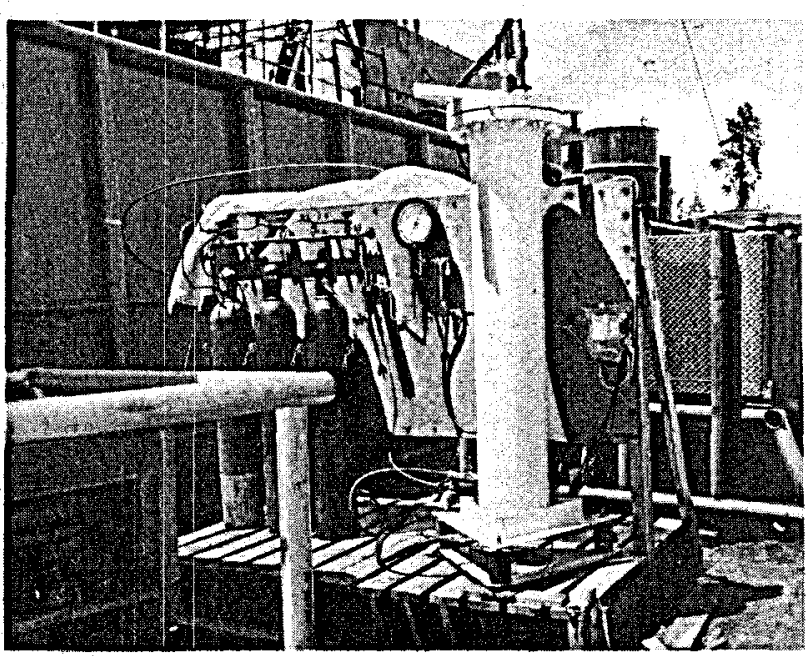

Fig. 9. Pressurization system for low flow rates. Water tank at right is pressurfized by compressed nitrogen. Amount of water in the tank is determined by welght on load cells at the base.

fracture experiments. The f1rst three described were designed by LASL Q-22 personnel. These three systems were used for low flow rates at closely controlled pressures and were hooked up to be used Interchangably.

a. Hydrology System. This unit was designed principally for measurement of the rock permeability at very low flow rates. It consisted of a $0.23-\mathrm{m}^{3}$ $\left(8-\mathrm{ft}^{3}\right)$ water tank that was pressurized by compressed n1trogen (F18. 9): A constant pressure up to 4.8 YPa (700 ps1) could be maintained during flow. The tank rested on three load cells which were used to weigh the amount of water displaced. This feature was also used during venting operations to measure the amounts of water recovered when pressure was released in the hole.

The equipment for the hydrology system was mounted on an open-air platform located bestde the drilling rig.

b. Accumulator System. Th1s system was designed for the fracture Initiation and extension experiments. Pressurization of the hole was accomplished by flowing water from three prepressurized accumulator tanks through a control valve. The tanks each held approximately $38<(10 \mathrm{gal})$ of water, pressurlized to $34.5 \mathrm{MPa}$ ( $5000 \mathrm{ps})$. Flow through the electropneumatic control valve could be accurately controlled at rates from 4 to $76 \mathrm{l} / \mathrm{min}$ ( 1 to $20 \mathrm{gpm}$ ). 


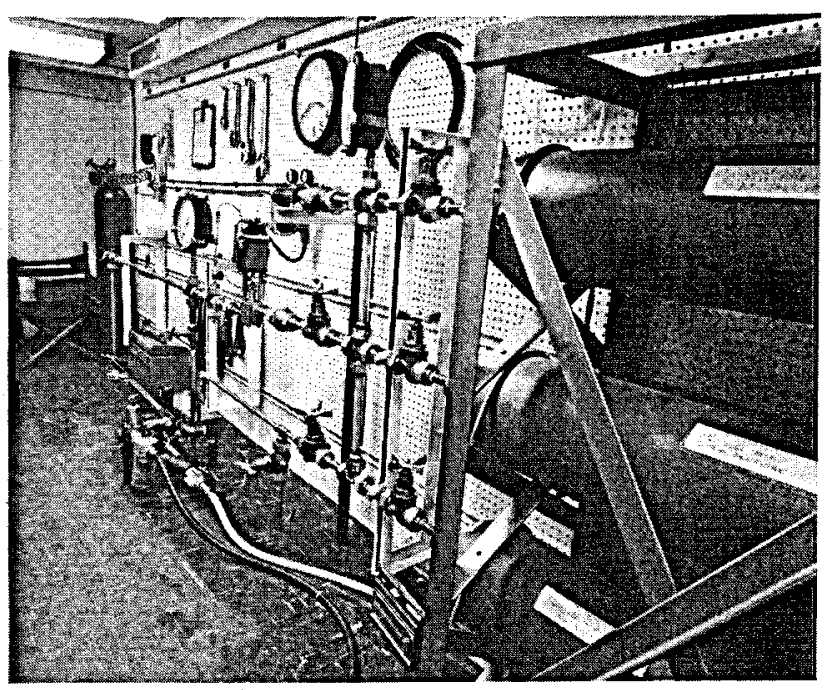

Fig. 10. Interior of trailer containing accumulator system and low-volume pump. Accumulator tanks with connecting piping and valves are shown on right. The low-volume alrdriven water pump used to charge the accumulator and for pressurizing the hole is mounted on the floor.

The accumulator system with 1 ts charging pump was contained in a trafler located near the drilling rig (Fig. 10).

c. Low-Volume Pump. The accumulators were pressurized with an air-driven water pump with a maximum pumping capacity of $6.6 \mathrm{l} / \mathrm{m}(1.75 \mathrm{gpm})$ at $34.5 \mathrm{MPa}$ (5000 psi). It was possible to pressurize the hole directly with the unit, bypassing the accumulators.

The power requirement of the pump was $0.05 \mathrm{~m}^{3} / \mathrm{s}$ (100 SCFM) of compressed air at 0.7.MPa (100 psi).

\section{d. High-Volume Pump. A truck-mounted}

high-pressure pumping unit was furnished by an o11we11 services contractor, the Western Company of Farmington, New Mexico. The pump was a positivedisplacement triplex unit, capable of a maximum flow of $606 \mathrm{l} / \mathrm{min}(160 \mathrm{gpm})$, powered by a 186-kW (250-hp) diesel engine (Fig. 11). Pressures and flow rates were recorded on a strip-chart recorder. The unit was also hooked into the LASL low-volume pumping system, so that pumping pressures could be monitored in the accumulator trailer.

3. Electronic Instrumentation. Capabilities for observing and recording the data from the following gauges and instruments were provided in the instrumentation trailer. a. Transducer for measuring annulus water

leve1;
b. Downhole geophone;
c. LASL sefsmic stations;
d. Load cells on hydrology tank;
e. Pumping pressure; and
f. TIme vs pumping pressure plotter.

VII. HOLE DEEPENING

\section{A. Driling}

On August 30, wh1le waiting for new Lynes packer elements to arrive at the drill site, it was decided to drill ahead with a Smith 25.1-cm-diam (9-7/8-in.) carbide-insert mining bit. The Inside diameter of the casing was only $25.3 \mathrm{~cm}$ (9.95 in.), but the bit went down through the casing without difficulty. Two short sections of the open hole, at depths of 853 and $1890 \mathrm{~m}$ ( 2800 and $6200 \mathrm{ft}$ ), required a sma11 amount of reaming. Drilling ahead began at 4:30 a.m. on August 31 using water as the drilling medium, and was concluded at a depth of $2040.8 \mathrm{~m}(6695.5 \mathrm{ft})$ on September 5. The penetration rate was approximately $2 \mathrm{~m} / \mathrm{h}(6 \mathrm{ft} / \mathrm{h})$.

\section{B. Logging and Coring}

After drilling was completed, the hole was washed to bottom with open-ended drill pipe using the standard circulation procedure developed in Phase $I^{14}$ When the temperature probe was run in the hole, approximately $12 \mathrm{~m}$ (40 ft) of $\mathrm{f} 111$ were encountered on bottom. The hole was washed to bottom again,

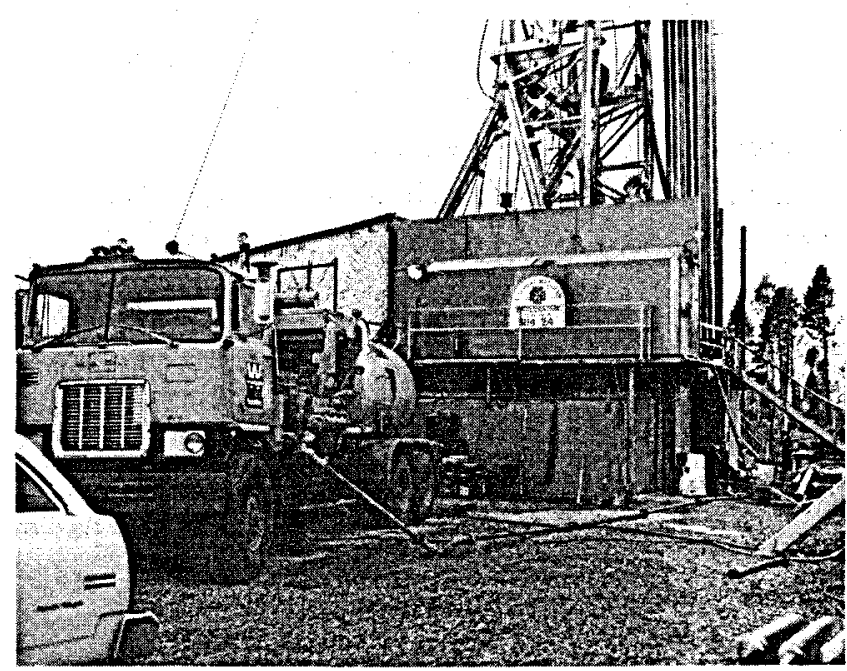

Fig. 11. Truck-mounted high-pressure pumping unit for high-volume flow rates. 


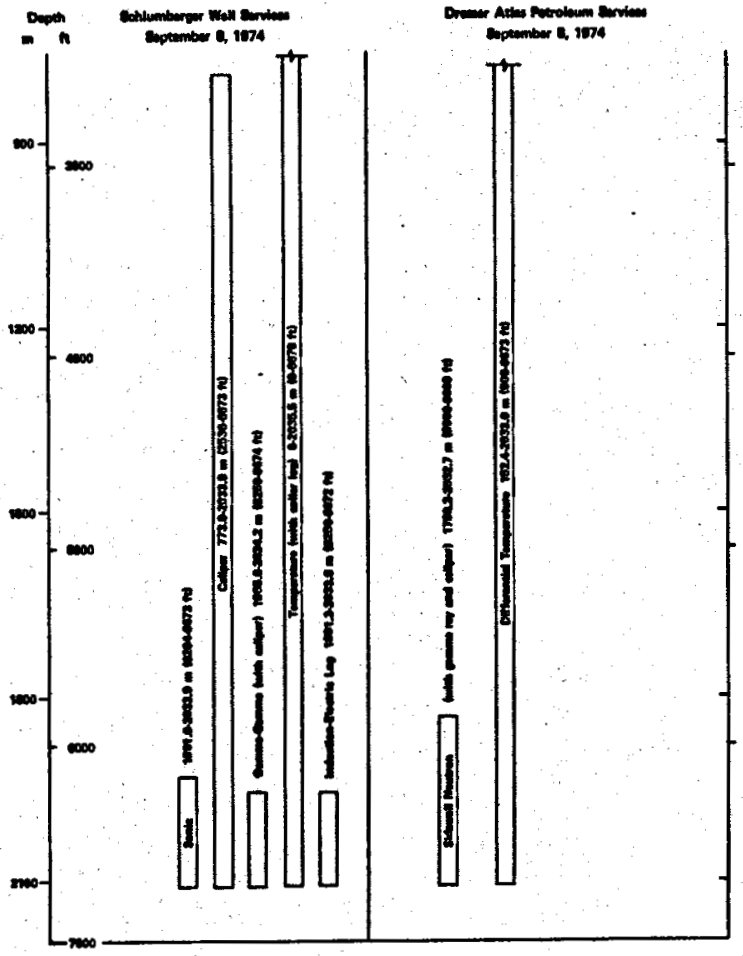

Fig. 12. Dlagnostic logging services performed in GT-2 on September 8,1974 .

circulated for $0.5 \mathrm{~h}$ and the drill pipe pulled up $2.1 \mathrm{~m}(7 \mathrm{ft})$ off bottom. The heavy LASL temperature probe was then run down Inside the pipe. With the tip of the probe resting on rock at the bottom of the hole, and the top $0.6 \mathrm{~m}$ (2 ft) of the probe st111 inside the drill pipe, a batch of $3 \mathrm{~m}^{3}(20 \mathrm{bbls})$ of 71-s-viscosity mud (Aquagel and Cellex) was pumped to bottom to reduce thermal convection. After $20 \mathrm{~h}$ of measurement, the extrapolated bottomhole temperature was $146.2^{\circ} \mathrm{C}$.

Following the temperature measurements, the hole was deepened to $2042.6 \mathrm{~m}(6701.5 \mathrm{ft})$ using a JOIDES core-b1t assembly. No core was recovered from thls run.

Diagnostic logging operations were then conducted in the hole as summarized in Fig. 12.

\section{Hydrology Testing}

The bottom of the hole was tested for permeability using a packer assembly consisting of three Johnston elements at the top of a 62-m (203-ft) section of drill collars. A 1-h flow test indicated zero Inflow at the 1981- to 2042-m (6498- to 6701-ft) Interval. A subsequent 7-h shut-in test indicated that a water pressure of nearly $13.8 \mathrm{MPa}$ (2000 ps1) was acting on the formation at the tested interval. Several fracture impressions were noted on the lower packer element, spaced about $15 \mathrm{~cm}$ (6 in.) apart, dipping 70 degrees.

\section{FRACTURE EXPERTMENTS--CEMENTED LINER}

Because of the fallure of the packers to hold satisfactorily in the open hole, It was necessary to resort to a cemented liner to conduct meaningful fracture experiments. Accordingly, arrangements were made with Halliburton 011 Well Cementing Company to cement a steel liner and pollshed-bore receptacle (PBR) in the hole.

\section{A. Liner Placement}

The bottom section of the hole was first filled with coarse sand (-No. 8 +No. 12) to a depth of 1989 m (6525 ft). A cement plug with its top surface at 1981.5 II (6501 ft) was then placed on the sand. The Iiner and PBR assembly, consisting of $64.2 \mathrm{~m}$ (210 ft) of 16.4-cm-1.d. (6.46-1n.) casing, was set on top of the cement plug on September 10, and cemented into place. The top $1.1 \mathrm{~m}(3.5 \mathrm{ft})$ of the assembly was made up with a flared, machined inner-surface section into which the $P B R$ mandrel on the end of the pipe ctring would seat.

After a 24-h wait to allow the cement around the Iiner to set, \& $15.6-\mathrm{cm}$-diam bit $(6-1 / 8-1 \mathrm{n}$.) was run down through the IIner, the cement plug was drilled and the sand washed out of the bottom of the hole. On September 13, the PBR mandrel assembly was seated with a total of $63.5 \mathrm{Mg}$ (140 $000 \mathrm{lbs}$ ) of drill-string weight.

\section{B. PBR Assemb1y Testing}

A series of pressurization tests was conducted In zone 7 at the 1981- to 2042-m depth (6498- to 6701-ft) during the following week in which pressures up to $17.2 \mathrm{MPa}(2500 \mathrm{ps}$ ) and flow injection rates of $454 \ell / \mathrm{min}(120 \mathrm{gpm})$ were obtained, using the highvolume truck-mounted pump. The downhole instrumentation cable pack-off assembly on top of the plpe string leaked continuously and finally ruptured. In order to repair this assembly; the pipe string had to be raised, which required breaking the PBR seal. After the $\mathrm{PBR}$ seal had been reset, rises in the annulus water level above the PBR began to occur during pumpIng. When the assembly was pulled out of the hole for Inspection, it was discovered that the nylon chevron seals in the PBR mandrel had been damaged during the reseating operations (F1g. 13). 


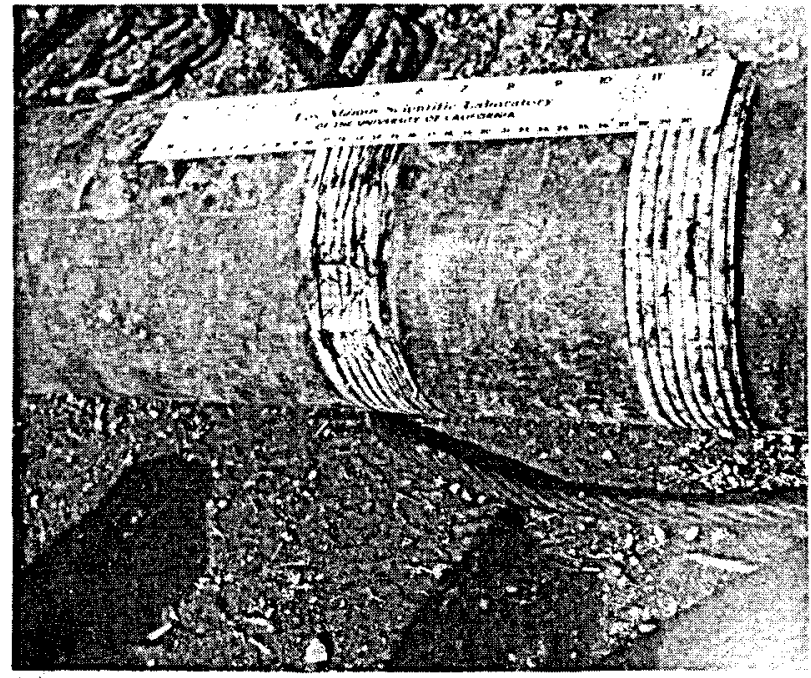

Fig. 13. Damaged chevron seals on the PBR mandrel.

Extensive temperature measurements in the bottom of the hole below the liner section during pumping seemed to Indicate that a fracture had been created or that an existing crack had been opened.

\section{c. Packer Testing in the Liner}

Because the seals on the PBR mandrel had been so severely damaged, it was necessary to seat a packer in the IIner for further pressurization tests. On September 21, a Baker 011 Tool packer was set in the Ifner at a depth of 1928 m (6325 ft). During the next 2 days, a Schlumberger spinner logging tool (Fig. 14) was used to test for water flow into the crack during pressurization experiments. Twenty logging runs were made during which increasing volumes of water up to $17 \mathrm{~m}^{3}$ (4600 gal) in a maximum single injection were pumped Into the crack at pressures of approximately $17.2 \mathrm{MPa}$ (2500 psi) and flow rates of 454 to $681 \mathrm{l} / \mathrm{min}$ (120 to $180 \mathrm{gpm}$ ). A later interpretation of the spinner logs indicated the existence of two fractures, between approximate depths of 1990 to $1993.4 \mathrm{~m}$ (6529 to $6540 \mathrm{ft}$ ) and 1999 to $2002 \mathrm{~m}$ (6559 to $6568 \mathrm{ft}$ ).

From September 25 through 27, the fracture system In the bottom of the hole was extended by pumping increased amounts of water into 1t. Quantities of 42, 76, and $136 \mathrm{~m}^{3}$ (11 160, 20000 , and $36000 \mathrm{gal}$ ) were injected separately at maximum pressures of $17.2 \mathrm{MPa}$ (2500 ps1) and maximum flow rates of 606 $\ell / m i n$ (160 gpm). During pumping, a small drop in the

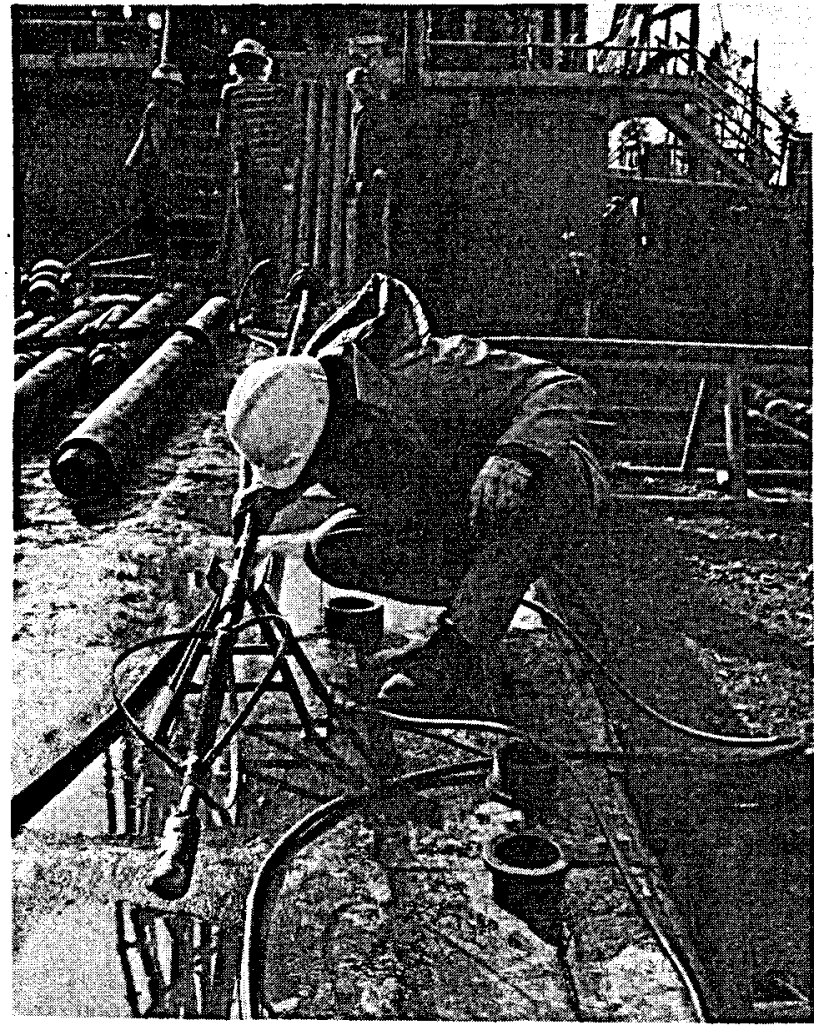

Fig. 14. Schlumberger spinner logging tool is examined on drilling rig catwalk. The rate of water flow through the tool is measured by the speed of small revolving blades in the section of the tool resting on the support.

annulus water level was usually observed. Upon ventIng the system, about half of the injected water was usually recovered.

On September 28, a sand-fracture experiment was conducted to prop the cracks open. The Western Co. pumped in $17 \mathrm{~m}^{3}$ (4500 gal) of a cross-linked polymer gel and $4.3 \mathrm{Mg}$ (9500 1bs) of sand (7500 1bs of No. 20-40 sand and 2000 1bs of No. 10-20 sand). Maximum pumping pressure was $20.3 \mathrm{MPa}$ (2950 psi) at a flow rate of $1438 \ell / \mathrm{min}(380 \mathrm{gpm})$. Monitoring of the pressure during controlled repressurization, vent, and shut-in experiments continued unt1l September 30. D. Perforation of Casing

In preparation for additional fracture experiments, the casing was perforated by Go-International Inc. on September 30. A total of 80 perforations were made in the 1941.6- to 1944.6-m (6370- to 6380ft) Interval, designated as Zone 8. A Johnston 
straddle packer assembly was then lowered Into the hole to enclose the 1934- to 1948-m (6345- to 6390ft) interval.

When the Interval was pressurized with the Western pump, the pressure rose to $12.8 \mathrm{MPa}$ (1850 ps1), but continuous flow up the annulus indicated the packer was leaking. The Johnston packers were pulled and the Baker packer was set in the liner above the perforated zone at a depth of $1929 \mathrm{~m}$ (6330 ft). Water was pumped in the hole for an hour at a maximum pressure of $13.4 \mathrm{MPa}$ (1950 psi). The system was shut in for $15 \mathrm{mln}$, then vented. Approximately $92 \%$ of the $7.6 \mathrm{~m}^{3}$ (2012 $\left.\mathrm{gal}\right)$ of water that had been injected was recovered.

E. Final Pressurization Experiments

On October 2, the Baker packer was set below the perforated zone to determine if there was a connection from below the liner to the perforations. Pumping continued for $2 \mathrm{~h}$ at $121 \mathrm{l} / \mathrm{m}(32 \mathrm{gpm})$ : The presgure rose to $15.1 \mathrm{MPa}$ (2185 ps1), but no connection to the annulus above the packer was observed. The system was vented and within $5 \mathrm{~h}$ approximately $85 \%$ of the water was recovered.

The Baker packer was pulled out of the hole, and the tool string made up with a bridge plug on the bottom. The plug was set at a depth of 1960 in (6432 ft) and the Baker packer at $1929 \mathrm{~m}$ (6328 ft), thus enclosing the perforations. Pressurization at a flow rate of $477 \mathrm{l} / \mathrm{min}(126 \mathrm{gpm})$ was inttlated and the pressure rose inmediately to $24.6 \mathrm{MPa}$ (3570 ps1). Pumping continued unt11 $10.3 \mathrm{~m}^{3}$ (2730 gal) of water had been injected. The system was then shut in and the pressure decay observed.

At 12:30 a.m., October 3, the bridge plug and packer assembly was loosened and then lowered to set the packer at $1957 \mathrm{~m}$ (6422 ft). The bottom section of the hole was pressurized to $15.2 \mathrm{MPa}$ (2200 psi) at a flow rate of $238 \mathrm{l} / \mathrm{min}(63 \mathrm{gpm})$. At that pressure, $a$ short but rapid rise in the annulus water level was observed, followed by a smaller, steady discharge of $11.4 \mathrm{l} / \mathrm{m}$ n ( $3 \mathrm{gpm}$ ) out the flow line. It was thought that two separate cracks, offset from each other but separated by unfractured rock, might exist in the lower gection of the hole and at the perforated zone. The rise in the annulus level might therefore be water that was efected through the perforations from the upper fracture when the lower fracture was expended by punping.

\section{REMOVAL OF LINER ASSEMBLY}

As soon as the fracture experiments were terminated, the bridge plug and packer assembly was pulled and washover operations began immediately to remove the cemented Iiner.

Considersble difficulty was encountered in washing over the PBR gection of the 1iner, as 1ts outside diameter was nearly the same as the inside diameter of the washover bit. The centralizer fins on the liner were also continuous sources of trouble. On two occasions, the washover shoe became stuck and the farring tools broke, requiring flshing operations to remove the tools from the hole. On October 11, the IIner assembly was finally retrleved, and a 25cm-d1am (9-7/8-1n.) full-face b1t with junk basket was run in to drill out the cement plug.

By 2:00 a.m. on October 12, the bit reached bottom at 2042 m (6701 ft) and dr1111ng ahead proceded.

\section{CONCLUSIONS}

During the pressurization experiments, only one definite Instance of breakdown and crack extension was noted. This occurred on August 6, at the 846to 873-m (2775- to 2865-ft) Interval. The Johnston recorder package showed that breakdown occurred at a pressure of $9.6 \mathrm{MPa}$ (1397 ps1), and crack extension at a pressure of $8.9 \mathrm{MPa}$ (1286 p81). In all the other pumping experiments where water was injected into the formation, it 18 belleved that crack intitiation had not taken place, but that pre-existIng cracks had been opened and extended.

Although the rock at depth in GT-2 appears to be extensively fractured, the leak-off rate was quite sma11. As a result of the hydrology tests and fracturing experiments, the Fenton Hill site was judged to be suitable for further development of the geothermal project.

Considering the costs that had been already Incurred in drilling to $2042 \mathrm{~m}$ (6701 ft), it was decided to deepen the hole to about $2750 \mathrm{~m}$ (9000 ft) and perform additional experiments at that depth before starting to dr111 a second hole.

\section{COMPARISON WTTH PLAN}

The actual measurements and experiments that were performed In Phase II are compared as follows with the planned experiments shown in Appendix A. 
A. Post-Drilling Measurements and Experiments

1. Hole-Filling Operations. Because the hole was drilled with water Instead of with air as was originally planned, this operation was not necessary.

2. Fluid-Media Diagnostic Logs. Logging operations In GT-2 have been described in the Phase I report. ${ }^{14}$ Additional $\operatorname{logs}$ were run after the hole was deepened to 2042 . I (6701 ft).

3. Measured and Computed Rock-Property Data. The elastic properties and density of the rock are presently being determined from the logs. Fractures and fractured zones were detected by the borehole televiewer. Dry-hole neutron logs were not run, so a comparison to the wet-hole neutron $10 g$ was not made. Full sets of electric logs were run, and they show great promlse of belng extremely useful. The electronic components of other types of logging equipment do not function well at the temperatures encountered near the bottom of the hole. It is felt that with continued study, the petrologic interfaces between varlous igneous and metamorphic facles may be determined from the logs.

4. Temperature Logging. Many temperature measurements were taken, and their interpretation will be the subject of a separate report.

5. Sonic Velocity Survey of the Borehole. As described in Section IV of this report, a sonic velocity survey of the area was completed.

6. Initial Eydrologic Studies. The hydrologic studies, briefly described in Section $v$, will be the subject of a separate report.

7. Large Hydraulic Fracture Experiment. Because of the existence of pre-existing fractures in the borehole walls and the failure of the open-hole packers to perform 8 expected, the fracture experiments did not occur as planned. The fracture experiments have been briefly described in Sections VI and VIII, and will be the subject of a separate report.

\section{Related Geophysical Measurements. Two of} the three proposed measurements (changing plezoelectric potential and radon level) were not completed due to time and manpower shortages. The tiltmeter survey was not completed because lightning strikes damaged the installed tiltmeters and replacements could not be obtained in time.

B. Subsequent Hydraulic Fracturing Experiments See comments in Item A.7 of this section.

\section{REFERENCES}

1. D. W. Brown, "The Potential for Hot-Dry-Rock Geothermal Energy in the Western United States," Hearings before the Subcomittee on Energy of the Committee on Science and Astronautics, 0.S. House of Representatives, Ninety-Th1rd Congress, First Session on H.R. 8628, H.R. 9658, Sept. 11, 13 , and 18, 1973, pp. 129-138.

2. D. W. Brown, M. C. Smith, R. M. Potter, "A New Method for Extracting Energy from 'Dry' Geothermal Reservoirs," Proc. Twentleth Annual Southwestern Petroleum Short Course, Texas Tech Univ., Lubbock, Texas, April 26-27, 1973, pp. 249-255.

3. B. C. Renich, "Geology and Ground-Water Resources of Western Sandoval County, New Mexico," U. S. Geological Survey Water-Supply Paper 620 (1931).

4. G. H. Woods, Jr. and S. A. Northrop, "Geology of the Nacimiento Mountains, San Pedro Mountains, and Adjacent Plateaus in Parts of Sandoval and Rio Arriba Counties, New Mexico," U. S. Geol. Survey 011 and Gas Inv. Prelim. Map 57 (1946).

5. R. L. Smith, R. A. Bafley, and C. S. Ross, "Structural Evolution of the Valles Caldera, New Mexico, and Its Bearing on Emplacement of Ring Dikes," U. S. Geol. Survey Prof. Paper 424 -D (1961).

6. C. S. Ross, R. L. Sm1th, R. A. Bailey, "Outline of Geology of the Jemez Mountains, New Mexico," New Mexico Geol. Soc. Twelfth Field Conf., Albuquerque Country (1961).

7. R. A. Balley, R. L. Smith, and C. S. Ross, "Stratigraphic Nomenclature of the Volcanic Rocks in the Jemez Mountains, New Mexico," U.S. Geol. Survey Bul1. 1274-P (1969).

8. R. L. Smith, R. A. Bailey, C. S. Ross, "Geologic Map of the Jemez Mountains, New Mexico," U.S. Geol. Survey Misc. Geo1. Inv. Map I-571 (1970).

9. J. P. Fitzsimmons, "Precambrian Rocks of the Albuquerque Country," New Mexico Geol. Soc. Twelf th Fleld Conf., Albuquerque Country (1961).

10. F. G, West, "Regional Geology and Geophysics of the Jemez Mountains," Los Alamos Scientific Laboratory report LA-5362-MS (1973).

11. W. D. Purtymun, "Geology of the Jemez Plateau West of the Valles Caldera," Los Alamos Sclentif1c Laboratory report LA-5124-MS (1973).

12. F. G. West, "Geohydrology of the Jemez Plateau," paper presented at the Annual Fall Meeting, 1973 American Geophy. Union, San Francisco, CA, Dec 10, 1973.

13. R. L. Aamodt, "An Experimental Measurement of In Situ Stress In Granite by Hydraulic Fracturing," Los Alamos Scientific Laboratory report LA-5605-MS (April 1974).

14. R. A. Pettitt, "Planning, Drilling and Logging of Geothermal Test Hole GT-2, Phase I," Los Alamos Scientific Laboratory report LA-5819-PR (Jan. 1975). 
15. W. D. Purtymun, F. G. West, R. A. Pett1tt, "Geology of Geothermal Test Hole GT-2, Fenton Hill Site," Los Alamos Scientific Laboratory report LA-5780-MS (Nov. 1974).

\section{APPENDIX A}

POST-DRILLING MEASUREMENTS REQUIRED FOR SITING OF EE-1

WITH SUBSEQUENT HYDRAULIC FRACTURING EXPERIMENTS

\section{PHASE II}

March 20, 1974

\section{A. Post-Drilling Messurements and Experiments}

For approximately 30 days following the complet1on of the drilling phase of GT-2, and while the drilling r1g is still over the hole, a serles of programmatically-orlented measurements and experiments w1ll be performed. The primary objective of these immediate post-drilling measurements and experiments is to obtain additional hydrologic, geologic, and in situ earth-stress and fracture-mechanIcs Information from GT-2 needed for making the final dectsion of whether to proceed with the drillIng of EE-1 at the Fenton Hill site.

1. Hole-Filling Operation. Because of the anticipated GT-2 bottomhole temperature- which may approach $200^{\circ} \mathrm{C}--\mathrm{a}$ carefully-controlled hole-filling procedure is needed for both safety reasons and to prevent the inadvertent thermal shocking of the rock exposed at the bottom of $\mathrm{GT}-2$.

The general plan is to lower a sealed and waterfilled string of large diameter drill pipe to the bottom of GT-2. Thls column of water will then be allowed to reach approximate thermal equilibrium with the surrounding rock--malnly by convective heat transfer across the annular atr gap between the pipe and the wellbore. The approach to temperature equiIfbrium w111 be monitored by a wireline thermometer lowered through the center of the water-filled drill string.

After the atr-filled annulus around the drill p1pe has been pressurlaed to above the water vapor pressure corresponding to the GT-2 bottomhole temperature, an impact-actuated sliding-sleeve valve, Installed near the bottom of the drill string, will be opened remotely by dropping a shaped, weighted object down the inside of the drill pipe from the surface. Hot pressurlzed water, flowing out of the drill pipe through small ports exposed by the silding-sleeve valve, will then slowly fill the annular gap. Makeup water will be added to the drill string until the annular water level is oufficiently above the depth below the surface corresponding to a rock temperature of $90^{\circ} \mathrm{C}$ (about $500 \mathrm{~m}$ ).

\section{Pluld-Media Dlagnostic Logs. In order of} their decreasing temperature sensitivity, the followIng diagnostic logs will be run by a commercial logging company. (Two separate logging companies may be required to obtain the desired set of $\log s$ at a bottomhole temperature approaching $200^{\circ} \mathrm{C}$.)

- Three-dimension sonic-velocity log

- Borehole televiewer 108

- Neutron 108

- Several electrode configurations of electric (resistance and self-potential) logs

- Temperature $\log s$ (two measurements, at the beginning and the end of the suite)

3. Measured and Computed Rock-Property Data. Based on the data obtained from the entire suite of diagnostic logs (both dry-hole and flufd-media) run in the openhole section of GT-2, the following rockproperty data will be avallable for the entire logged Interval of crystalline basement rock exposed in GT-2.

\section{In S1tu Elastic Properties and Density.}

(1) Compressive velocity ( $P$ wave)*

(2) Shear velocity (S wave)*

*From the 3-D sonic log. 
(3) Density from the density (scattered

gamma) $10 g$
(4) Poisson's ratio*
(5) Young's modulus*

b. Fracture Determination. The presence of any open fractures or fractured zones will be Indicated primarily by the borehole televiewer $10 \mathrm{~g}$, and possibly confirmed by a comparison of the dryand wet-hole neutron logs. The two comparative neutron logs will be run as an experiment to determine if water-filled fractures can be detected by a comparison of neutron logs.

\section{c. Electrical Properties. Several con-} ventional oil-field-type electric logs will be run primarily as an experiment to determine which, if any, show promise for logging in basement rocks, whose electrical resistances are much higher than those of sedimentary rocks. (The resistances are higher due to the relatively low percentage of pore space avallable for the primary electrical conductor, water.)

Natural uncemented fractures should give the appearance electrically of being a sheet conductor. The depth of investigation (In this case, horizontal distance from the borehole) is primarily a function of the electrode spacing. It may therefore be possible to make Inferences as to the rock fractures surrounding the borehole by using a series of sondes with an increasing depth of penetration. Such a series would include the following electric logs: microcontact, guard, induction, short-normal, longnormal, and lateral.

\section{d. Petrologic Changes Within the Precam-}

brian Basement. Significant changes in the natural radioactive background level, as measured by the gamma log, may indicate petrologic interfaces between the various igneous and metamorphic facies occurring within the Precambrian basement complex, as was the case in GT-1. Obviously, this type of information is not as necessary with a continuous coring program, but the ability of the gamma 108 to differentiate between various types of crystalline rock, if this can be adequately demonstrated, would

*Computed from the 3-D sonic and density logs. be a very useful tool for subsequent geothermal drilling programs.*

4. Temperature Logging. The thermal recovery of the water-filled hole will be monttored by a sequence of temperature logs. The first two of these logs w111 be run by the selected commercial logging company, just after filling GT-2 with water and again at the end of the series of diagnostic logs listed above. After the commercial logging company has been released, additional temperature logs will be run with LASL equipment (if it is avallable by then).

The object of this sequence of temperature logs, which w11l probably extend over several months, 1s to Investigate the perturbation of the true temperature profile in a region of high heat flow, resulting from the drilling and the presence of a large-diameter water-filled hole:

\section{Sonic Velocity Survey of the Borehole. An} integrated sonic velocity survey of the entire drilled Interval--surface volcanics, Paleozolc sediments, and the Precambrian basement--will be run by a commercial logging or geophysical company. This velocIty survey, to be performed in several stages with a surface mounted energy source and a downhole geophone, will be used to provide velocity correlations needed in subsequent downhole acoustic measurements and fracture experiments. In addition, these integral velocity determinations will be used to provide scale factors to correct, to true compressional velocities, the less-than-absolute velocity data obtained from the 3-D incremental sonic-velocity logs.

This sonic-velocity survey will be performed with a system referred to as a "Vibroseis," an integrated system using a frequency-varlable surfacemounted sonic energy source (mechanical), coupled to a downhole wireline geophone.

The Vibrosels system will also be used to obtain very precise sonic travel-time data (both $P$-wave and S-wave veloctities) for each of the surface-mounted geophone stations to be used to monitor the planned large-scale hydraulic fracture at the bottom of GT-2. After the exact locations for this close-in array

*In addition, the strike and dip of the Precambrian surface underlying the Fenton Hill Site will be accurately determined from the depth-to-basement measurements obtained from the gamma logs from GT-2 and the two subsequent energy-extraction holes (EE-1 and $\mathbf{E E}-2$ ). 
have been selected, the truck-mounted sonic energy source will be sequentially located at each of the surface detection stations, with the downhole wireIine geophone located at the bottom of GT-2. In this way very precise sonic travel-time data w1ll be obtained from the botton of GT-2 to each of the surface detection stations. Using these very precise velocity data and known ray paths, combined with double or triple detection redundancy, it will be possible to compute spatially-accurate focl for fracture-associated acoustic events.

6. Inftial Hydrologic studies. The purpose of this intial set of measurements 18 to determine the prefracturing permeability of the section of Precambrlan rock penetrated in GT-2. These experiments will be made using a single surface-actuated packer set at 150-m intervals up from the bottom of the hole, or at successively h1gher Interfaces between rock types if this appears to be more promising.

To measure the permeability of each successively longer Interval of exposed basement rock, the pressure decay from surface pressurization levels of 30 and 60 bars will be accurately recorded over a significant perfod of time. Initially, an instantaneous head infection test will be used; however, if the field results indicate that confirmation by another method is advisable, either a constant-head method or the recovery from an average-flow method will be used. The fleld-testing methods and mathematical analysis of the flow of fluids through fractured porous media are not at all routine as evidenced by the rather divergent papers on the subject. The testing at two levels of Infection pressure should help to define the relationship of increased permeabillty with increased over-pressure.

7. Large Hydraul1c Fracture Experiment. Prior to the beginning of the drilling phase for the planned two-hole energy extraction experiment, a rather specific set of hydraulic-fracturing-related data must be obtained from GT-2. These data will be obtained by creating with water a relatively large-120- to 150-m radius--hydraulic fracture near the bottom of GT-2 using, If possible, a pump supplied by an ofl-field service company. The significant data and results that will be obtained from this experiment are as follows:

$$
\begin{aligned}
& \text { - Fracture orientation; } \\
& \text { - Fracture-initiation pressure; }
\end{aligned}
$$

- The role of stress concentrations--at the well bore, at the bottom of the hole, and adjacent to packers-on fracture termination;

- Existence of a preferred direction of fracture extension;

- Fracture extension pressure as a function of volume;

- Fracture fluld leak-off rate;

- The pressure-volume relationship for the reopened (repumped) fracture;

- The least compresstve stress, $\mathrm{s}_{3}$.

8. General Procedure. The "big" hydraulic fracture at the bottom of GT-2 w111 be produced in two stages: a fracture intiation stage followed by a fracture extension stage. To lessen the outward flow Impedance of the circulating fluld from the wellbore, a continuous fracture that emanates from the side of the bore in a vertical line is desirable. However, to prevent vertical flow discontinuities from offset or en echelon fracture zones within the extending fracture, a single point source for the fracture is even more desirable.* In order to realize the advantages of both point and line sources, it is planned to Initlate the fracture in a small ( $3 \mathrm{~m}$ ) packed-off zone centered $15 \mathrm{~m}$ above the bottom of the hole using a very low flow rate. After removing the lower packer and relocating the upper packer $30 \mathrm{~m}$ above the bottom of the hole, this inftal fracture will be gradually extended both upwards towards the relocated packer and downwards towards the bottom of the hole (as well as radially outwards). With a carefully controlled pumping rate, a single continuous vertical fracture should result over the bottom $30 \mathrm{~m}$ of $\mathrm{GT}-2$.

b. Detailed Procedure. For the intial stage two packers (seals) that are connected to the surface by a high pressure line (drill pipe), will be used to Isolate a 3-m interval of the wellbore centered 15 in above the bottom of the hole. This straddled Interval will be pressurized with water from the surface using a comerctal pump and a hydrau11c pressure accumulator. The pressure in the zone below the packer assembly w111 be monitored by a bourdon gauge-clock recorder (Amerada bomb). The

*At least one (1f not more) vertical flow discontinuitles were produced In the "big" fracture of GT-1 by flowing from a line source--in this case 40-m packed-off zone. 
pressure and flow to the sealed-off Interval will be continuously monitored at the surface. Acoustic events generated by this operation will be monitored by a downhole triaxial geophone (lowered on a wire line through the center of the drill pipe and seated just above the upper packer), and by the surface array of detection equipment.

The pressure to initially "break down" the rock at the wellbore--that is, to initiate a vertical tensional fracture--will be determined at flow rates similar to those used in the GT-1 incrementel fracture experiments: about $30 \mathrm{cc} / \mathrm{sec}(0.5 \mathrm{gpm})$. The wellbore pressure at fracture intiation will be obtained using the technique first developed during the GT-1 fracturing experiments: to determine, at a constant pumping (flow) rate, the pressure level corresponding to the sudden decrease in the previous1y constant rate of pressure Increase with flow resulting from the compression of the column of fluid in the wellbore. This drop in the analog-computed value for $\frac{d P}{d V}$ will signal the point at which the formation inftially fractures and starts accepting fluid.

For the second stage of the big fracture exper1ment, a single packer will be located about $30 \mathrm{~m}$ above the bottom of the hole. The Interval below this packer will be pressured in stages 80 as to extend the intial small fracture both upwards towards the new packer position and downwards towards the bottom of the hole. The pumping rate during this fracture extension operation will be approximately that used to form the initial small fracture. The hydraulic pressure and flow rate will be recorded during the growth of the fracture. A downhole, threecomponent geophone will be used to infer the principal direction of fracture growth.

When the fracture has been extended over the entire interval from the packer to the bottom of the hole, the pumping rate will be slowly increased as the fracture is extended out to a radius of approximately $150 \mathrm{~m}$. The pressure required to extend the fracture should be several tens of bars below the fracture intiation pressure and, at a constant flow rate, should slowly decrease towards the value of the lesst compressive stress with increasing fracture volume.

Following the completion of pumping, the fracture w111 be shut in at the then existing fracture extension pressure. The fracture pressure which theoretically should decay to the value of the local least compressive stress if given sufficient time, will be recorded for a time approaching 24 hours. The post-fracturing permeability can then be contrasted with the prefracture value.

There are two available ways of monttoring the resulting fluid leakoff from this large pressurized crack after a given period of time. The first is to measure the volume of fluld required to reestablish the Intial shut-in pressure. The second is to allow the crack to collapse after a given period of time, and to measure the difference between the fluid pumped into the crack and the fluid recovered from 1t. The former method requires several assumptions concerning fracture stability and the influence of pore pressure (In a state of inciplent tension rather than the usual compression); and the latter depends on the difference between two large numbers and is complicated by the presence of other possible fluid leakage paths (for example, packer or drill-pipe joint leakage).

The fludd leakoff rate from the large fracture will be of great interest, and will be monitored for at least 24 hours following the end of pumping. When the 150-m-diam crack is allowed to collapse, the partial return of the $190 \mathrm{~m}^{3}$ ( $50000 \mathrm{gal}$ ) of water, which is expected to be used in forming this large fracture, w111 be measured. The water temperature will also be measured to determine the relative heat exchange of the system. The return flow of the hot water from the collapsing crack will be controlled by a throttling valve at the surface.

Following a series of fracture inflation and deflation experiments--and the assoclated fluid leakoff determinations--the fracture pattern at the wellbore w 111 be "photographed" in a static, but pressurized condition. This "picture" will be obtained by using a magnetically-oriented ball-actuated inflatable impression packer hung below the pressuresealing packer. The resulting fracture impression on the soft rubber (or plastic) outer packer sleeve will give both the fracture orlentation and its actual width.

The fracture orlentation (azimuth) will be obtained by using a combination of the following technfques: surface acoustic detection, downhole acoustic detection, and an oriented impression packer survey. The potential location of hydraulic-fracture assoclated 
events--using a close-in surface array of acoustic sensors--possibly defining both the perimeter and the azimuth of the fracture--has already been discussed above.

For this hydraulic fracture, a locked-1n, downhole, three-component geophone will also be used. The two horizontal instruments should provide the azimuthal orientation of fracture events and, coupled with the vertical component, should also provide the vertical location of events (1.e. elther above or below the packer position).

However, because of the delay in ordering the 22-conductor cable, additional downhole Instrumentation-such as a sensitive acoustic $\Delta P$ transducer -w1ll not be avallable, possibily precluding the determination of fracture radius during this experiment.

Because of the importance of knowing the fracture orfentation before locating the exact drilling sites for $\mathrm{EE}-1$ and $\mathrm{EE}-2$, It will be necessary to develop a high-temperature (up to $200^{\circ} \mathrm{C}$ ) Inflatable Impression packer, as a positive backup to the more speculative acoustic methods of determining fracture orientetion. This tool will be used to determine -at least in the wellbore--the azimuth of the hydraulic fracture formed at the bottom of GT-2.

8. Related Geophysical Measurements. During the formation of the big hydraulic fracture at the bottom of GT-2, three surface-monitored geophysical experiments are planned if time and manpower permit. These experiments are related to changes in the earth's stress field resulting from the formation of this large fracture.

In the first of these experiments, an orthogonal array of surface electrodes w1ll be used to monitor the changes in the electric potential occurring at the surface during fracturing. It is hoped that these measurements--using one pair of electrodes parallel to, and the other pair across the expected fracture direction-w111 delineate the plezoelectric potential field generated by the stress field developed by pressurization during the hydraulic fracturIng experiment. During the hydraulic pressurization of the wellbore prior to fracture inftiation, this Increasing piezoelectric potential should drop suddenly when the rock fractures and the induced stress fleld is relleved.
In the second of these experiments, any $\mathrm{d} 1 \mathrm{~s}-$ placement of the earth's surface resulting from the large-scale hydraulic fracturing experiment will be measured with a three-component array of directional t1ltmeters surrounding GT-2, A fourth tiltmeter, located in a quiet area some distance from GT-2, w111 be used for a background determination. These tiltmeters are to have a sensitivity of $10^{-6}$ radian. The primary purpose of these measurements is to record any earth tilts associated with the big hydraulic fracture, both as a possible means of determining fracture orientation and for use in environmental studies.

In addition, these tiltmeters will be used to monitor changes in the configuration of the earth's surface caused by transient stress waves with periods of from $10^{-2}$ to $10^{6}$ seconds, caused by microearthquakes, earth tides, or premonitory earthquake stress accumulations. From recently published studles, it appears that one method of predicting earthquakes is by monitoring various anomalous phenomena such as t1lts of the ground surface and the ground water (phreat1c) surface, and increases in the radon level caused by the rapid change in the local stress field that occurs just before an earthquake.

The radon level will be monitored by sampling the air from a shallow borehole near the drill site as the third experiment. Increased microfracturing resulting from increased stress levels exposes more area for the release of radon.

B. Subsequent Hydraulic Fracturing Experiments in GT-2

1. Obfective and Scope. The primary objective of this series of experiments is to investigate in detall the variation, in both magnitude and direction, of the minimum compressive earth stress $\left(S_{3}\right)$ with depth. An adjunct to this primary objective will be the development of various downhole techniques and Instrumentation capable of characterizing hydraulic fractures, with regard to both geometry and orientation.

The secondary objective for this serles of experiments is an Investigation of methods of measuring and possibly controlling the direction of crack propagation. Associated with this fracture study will be an investigation of the stability, while pressur1zed, of the large hydraullc fracture previously formed at the bottom of GT-2. For these studies 
a knowledge of the variation of $s_{3}$ with depth will be essential. In addition, the development of instrumentation techniques for defining the radius vector for the discrete acoustic (tensional-cracking) events associated with the developing fracture system will be needed.

2. Incremental Small-Scale Fracture Experiments. In order to measure the variation in $\mathrm{s}_{3}$ with depth, a series of 10 to 20 small-scale hydraulic fracturing experiments will be performed in the openhole section of basement rock penetrated in GT-2. In each of these experiments, a short $3-\mathrm{m}$ interval of the wellbore will be isolated between packers (pressure seals), and pressurized through a high-pressure line (drill pipe) extending from the surface. The upper packer of the straddle packer assembly w111 contain a "polished bore receptacle" to permit the landing and seating of a downhole Instrumentation and control package.

In order to keep the test location as quiet as possible during these omall-scale fracturing experiments, all motorized surface equipment will be turned off with electrical power being supplied from a nearby power line. To minimize the transmission of spurlous sonic signals down the long pressure line, a hydraulic accumulator (rather than a pump) will be used to supply the pressurizing water flow through a surface flow-control system.

The downhole instrumentation and control package will include the following.

a. Three-component geophone (two horizontal and one vertical); magnetically oriented.

$$
\text { b. Wide-range (0-7500 psia) pressure }
$$
transducer.

c. Ball release system (to actuate the integral impression packer).

d. Water sampler for geochemical studies.

The close-In acoustic signals recorded by the downhole magnetically-oriented geophone array will be used in studies which may lead to a method of determining the fracture orientation, and also possibly the vertical extent of the fracture.

An inflatable Impression packer, located between the two straddle packers and an integral part of the experimental packer assembly, w1ll be used to take an oriented Impression of the pressurized fracture at the end of each fracture experiment. This packer impression will show not only the fracture orientation (azimuth) at the wellbore, but also the fracture width in a static, but pressurized, condition. These impression packer measurements will be needed in assessing the resuits of the acoustic fracture-orientation experiments.

From the difference in the time of arrival of the sonic signals transmitted through the rock (recorded by the three-component geophone) and through the water, the distance to discrete fracture events may possibly be resolved. (Obviously considerable engineering development work will be needed in this area.)

The measured pressure decay of the isolated, pressurized fracture w111 give a direct measure of the local least compressive stress, $s_{3}(z)$. In addition, this Information will be useful in evaluating the fluid leakoff from discrete small-scale fractures, and for an assessment of the in situ rock permeability in an almost-neutral state of stress.

- Based on the information derived from the continuous coring, it may be possible to utilize various rates of pressurization to fracture rock of similar type or strength, while determining the variation of $s_{3}$ wth depth. The more rapid the rate of pressurization, the more nearly the fluid approaches the condition promulgated for a "nonpenetrating fluid." A nonpenetrating fluid theoretically does not raise the pore pressure and thus does not reduce the apparent strength of the rock. The relatively low permeability of the basement rocks found in GT-1, if generally pervasive, should complement the conditions that occur when a nonpenetrating fluld is used. It has been suggested that the rate-of-strain increase used in some commercial fracturing operations approaches impact loading, thus giving a high apparent material strength. The establishment of a family of loading curves would be of considerable englneering and scientific value.

c. Repumping the "Big" Hydraulic Fracture

The "big" hydraulic fracture previously formed at the bottom of GT-2 will be repumped to 1 ts original volume with the same packer location. However, for this experiment, the downhole instrumentation and control package will be used to monitor the fracture events. During this experiment, the closeIn surface geophone array will be again used in studying fracture-associated sonic events. 
The fracture will then be extended beyond its previous size (volume) by supplying (1) a constant flow from a relatively quiet electrically-driven p1ston pump, or (2) flow impulses from a 30-gallon hydraulic accumulator.

The continuing extension of this fracture system w11 then be studied using the downhole fracturelocation techniques developed during the previous sma11-scale incremental fracturing experiments, in conjunction with fracture-related acoustic event foct determined from the surface geophone array. As a part of this atudy, the "big" fracture will be shut In under various conditions and acoustically monitored to determine whether there is a tendency, while In a "static" but pressurized condition, for the fracture to spontaneousiy extend in a preferred direction. 